\title{
Survival of Adult Spiral Ganglion Neurons Requires erbB Receptor Signaling in the Inner Ear
}

\author{
Konstantina Stankovic, ${ }^{1,3 \star}$ Carlos Rio, ${ }^{1 *}$ Anping Xia, ${ }^{1}$ Mitsuru Sugawara,,${ }^{1,3,4}$ Joe C. Adams, ${ }^{3}$ M. Charles Liberman, ${ }^{3}$ and \\ Gabriel Corfas ${ }^{1,2}$ \\ ${ }^{1}$ Division of Neuroscience, Children's Hospital, Boston, Massachusetts 02115, 2Department of Neurology, Harvard Medical School, Boston, Massachusetts \\ 02115, ${ }^{3}$ Department of Otology and Laryngology, Harvard Medical School and Eaton-Peabody Laboratory, Massachusetts Eye and Ear Infirmary, Boston, \\ Massachusetts 02114-3096, and ${ }^{4}$ Department of Otolaryngology, Head and Neck Surgery, Tohoku University Graduate School of Medicine, Sendai
} 980-8574, Japan

Degeneration of cochlear sensory neurons is an important cause of hearing loss, but the mechanisms that maintain the survival of adult cochlear sensory neurons are not clearly defined. We now provide evidence implicating the neuregulin (NRG)-erbB receptor signaling pathway in this process. We found that NRG1 is expressed by spiral ganglion neurons (SGNs), whereas erbB2 and erbB3 are expressed by supporting cells of the organ of Corti, suggesting that these molecules mediate interactions between these cells. Transgenic mice in which erbB signaling in adult supporting cells is disrupted by expression of a dominant-negative erbB receptor show severe hearing loss and $80 \%$ postnatal loss of type-I SGNs without concomitant loss of the sensory cells that they contact. Quantitative RT-PCR analysis of neurotrophic factor expression shows a specific downregulation in expression of neurotrophin-3 (NT3) in the transgenic cochleas before the onset of neuronal death. Because NT3 is critical for survival of type I SGNs during development, these results suggest that it plays similar roles in the adult. Together, the data indicate that adult cochlear supporting cells provide critical trophic support to the neurons, that survival of postnatal cochlear sensory neurons depends on reciprocal interactions between neurons and supporting cells, and that these interactions are mediated by NRG and neurotrophins.

Key words: neuregulin; cochlea; hearing; GDNF; neurotrophin; erbB

\section{Introduction}

Degeneration of primary auditory neurons [spiral ganglion neurons (SGNs)] is an important component of sensorineural hearing loss, and long-term survival of SGNs is critical for success of cochlear prostheses. Survival of adult SGNs depends on the integrity of cells of the organ of Corti, particularly the hair cells with which SGNs make synaptic contact. Acoustic trauma or ototoxic antibiotics, which primarily destroy hair cells, lead to secondary degeneration of SGNs. Degeneration of peripheral axons of SGNs is detectable within days after hair cell loss, and degeneration of SGN somata is widespread within weeks in regions of hair cell loss (Johnsson, 1974; Liberman and Kiang, 1978); however, some SGNs survive for months, if not years, after severe hair cell loss. There is histological evidence that supporting cells in the organ of Corti may contribute to SGN survival in the absence of hair cells. For example, histopathologic studies of human cochleas suggest a correlation between the extent of supporting cell loss and the

\footnotetext{
Received March 1, 2004; revised July 30, 2004; accepted Aug. 17, 2004.

This work was supported by National Institute on Deafness and Other Communication Disorders Grant R01 DC04820 (G.C.) and by a Howard Hughes Medical Institute physician postdoctoral fellowship (K.S.). We thank Dr. Lou Reichardt for providing the NT3-LacZ mice, Dr. Urs Berger for help with in situ hybridizations, and Nazia Akhtar and Heather Mason-Suarez for excellent technical help.

${ }^{*} K$. S. and C. R. contributed equally to this work.

Correspondence should be addressed to Dr. Gabriel Corfas, Division of Neuroscience, Children's Hospital, 300 Longwood Avenue, Boston, MA 02115. E-mail: gabriel.corfas@childrens.harvard.edu.

D01:10.1523/JNEUROSCI.0733-04.2004

Copyright $\odot 2004$ Society for Neuroscience $\quad$ 0270-6474/04/248651-11\$15.00/0
}

magnitude of SGN loss (Johnsson, 1974; Schuknecht, 1974; Suzuka and Schuknecht, 1988). In addition, recent analysis of transgenic mice with complete absence of hair cell formation but with differentiated supporting cells and limited expression of neurotrophins demonstrated long-term survival of SGNs (Xiang et al., 2003). Nevertheless, current understanding of the signaling pathways mediating SGN survival in the adult ear, and the possible roles of the supporting cells in that process, is rudimentary.

Although supporting cells of the organ of Corti are derivatives of the otic capsule (Fekete and $\mathrm{Wu}, 2002$ ), they have some characteristics of glia, which derive from the neural crest or the germinal layers of the neural tube. For example, supporting cells express several glial markers, including vimentin (Anniko et al., 1986), S100 (Pack and Slepecky, 1995), glutamate-aspartate transporter (GLAST) (Furness and Lehre, 1997), low-affinity neurotrophin receptor p75 (Vega et al., 1999), and the glial fibrillary acidic protein (GFAP) (Rio et al., 2002). Morphologically, supporting cells closely ensheath the unmyelinated terminal processes of SGNs near the hair cell synapse in a manner similar to that of astrocytes and perisynaptic Schwann cells at other synapses. Thus, interactions between SGNs and supporting cells may contribute to cell survival in the organ of Corti by mechanisms similar to those involved in neuron-glia interactions.

The neuregulins (NRGs) are trophic factors that play key roles in neuron-glia interactions in the peripheral and CNS (Adlkofer and Lai, 2000). NRGs are members of the EGF family of growth 
factors and signal through the tyrosine kinase receptors erbB2, erbB3, and erbB4 (Falls, 2003). In the nervous system, NRG1 is expressed primarily by neurons, including many peripheral sensory neurons (Corfas et al., 1995). In the cochlea, NRG1 is expressed by SGNs (Morley, 1998), suggesting that NRG1-erbB signaling may be important for cell-cell interactions in the cochlea.

To understand the role of NRG-erbB signaling in the inner ear, we studied the pattern of expression of NRG1 and erbB receptors in the cochlea. We found that although the ligand is expressed by the sensory neurons, the receptors are expressed primarily by supporting cells. To determine the roles of NRG1-erbB signaling in the interactions between SGNs and supporting cells, we analyzed the cochleas of transgenic mice expressing a dominant-negative erbB4 receptor (DN-erbB4) in supporting cells of the postnatal cochlea under the control of the GFAP promoter. The mutant receptor forms nonfunctional dimers with all NRG1 receptors, erbB2, erbB3, and erbB4, thus rendering them nonfunctional (Chen et al., 2003; Prevot et al., 2003). We found that the cochlea of transgenic mice develops normally, but $80 \%$ of SGNs die several weeks after birth, resulting in severe hearing loss. SGN degeneration in this mouse model is restricted primarily to type I SGNs and occurs without concomitant loss of hair cells. Quantitative RT-PCR analysis of neurotrophic factor expression shows that a key neurotrophin, NT3, is downregulated in the transgenic cochleas. These data are consistent with the view that adult cochlear supporting cells play a role in the maintenance of cochlear innervation, probably by providing critical trophic support to the neurons, and that this depends on erbB signaling in the supporting cells.

\section{Materials and Methods}

Generation of transgenic mice. The human GFAP promoter (Brenner et al., 1994) and the dominant-negative erbB4 cDNA (Rio et al., 1997) were used to generate the GFAP-DN-erbB4 transgenic mice as described in Chen et al. (2003). Mice carrying the transgene were identified by PCR on genomic DNA extracted from tail clips. Tail clips were incubated overnight in $500 \mu \mathrm{l}$ of lysis buffer ( $100 \mathrm{~mm}$ Tris $\mathrm{HCl}, \mathrm{pH} 8.5,5 \mathrm{~mm}$ EDTA, $0.2 \% \mathrm{SDS}, 200 \mathrm{~mm} \mathrm{NaCl}$ ) with $5 \mu \mathrm{g} / \mathrm{ml}$ proteinase $\mathrm{K}$ at $58^{\circ} \mathrm{C}$. The supernatant was precipitated with isopropanol, and the genomic DNA was resuspended in $100 \mu \mathrm{l}$ of TE buffer. One microliter aliquots of DNA were amplified in a $25 \mu \mathrm{l}$ of PCR with the $5^{\prime}$ primer TGCTGAAGGAATGGTGTGC and 3' primer CTTGTCGTCATCGTCTTTG. The PCR products were analyzed by agarose gel electrophoresis. Hemizygous mice of each line were intercrossed, and homozygous mice were identified by Southern blot or quantitative genomic PCR before postnatal day 20 (P20), or based on their ataxia, head bobbing, inability to swim, and weak or absent Preyer's reflex at later ages.

The NT3 mutant mice used for these studies (courtesy of Dr. L. Reichardt, University of California San Francisco, San Francisco, CA) were generated by targeted replacement of the NT3-coding exon with a construct containing a lacZ gene cDNA and the PKCneo marker (Farinas et al., 1994).

Histological analysis. For histopathological analysis of the cochlear phenotype, cochleas were fixed with mixed aldehydes, osmicated for $1 \mathrm{hr}$ $\left(1 \% \mathrm{OsO}_{4}\right)$, decalcified, dehydrated, embedded in plastic, and sectioned at $40 \mu \mathrm{m}$. For each case, the cochlear spiral was reconstructed in threedimensional (3-D), using Neurolucida (MicroBrightField, Colchester, VT) software and tracking the heads of pillar cells as the reference point for cochlear lengths (mean length $=6.53 \mathrm{~mm} ; \mathrm{SD}=0.35$ ). From these $3-\mathrm{D}$ data, the distance from the base was computed for each section through the duct, using custom software. Cochlear location was converted into frequency according to a frequency map described by Mueller et al. (2004), modified according to data on the range of tuning frequencies for mouse auditory nerve fibers (Taberner and Liberman, 2003). To accomplish this modification, Mueller's simple logarithmic fit was mod- ified to a power function of the form suggested by Greenwood (1990) as follows: $f(\mathrm{kHz})=9.8 *\left(10^{\mathrm{d}^{\star} 0.92}-0.68\right)$, where $d$ is the normalized distance from the cochlear apex $(0-1)$.

A standard cytocochleogram was prepared for each ear using oilimmersion objectives [100×; numerical aperture (NA) 1.30] and DIC optics. In each section through the cochlear duct, the number of present and absent hair cells was assessed throughout the entire section thickness. Evaluations of both the nuclear and cuticular regions were used to make these assessments.

Neuronal counts were made in the osseous spiral lamina near the habenula in tangential sections through the lower basal, upper basal, and second turns. In such osmium-stained plastic sections, all myelinated fibers could be counted using high-power (100×; NA 1.30) DIC optics. For each case to be evaluated, one section was selected from each of the three cochlear regions where a half turn of the cochlear spiral is cut tangentially. The selected section included the peripheral edge of the spiral limbus, thus ensuring that the plane passed near the habenula perforata but was far enough central to it that all type-I auditory nerve fibers would be myelinated (Liberman, 1980). In each selected section, several fascicles of the peripheral axons of auditory nerve fibers were cut in cross section. An observer (blind to the genotype of the animals) counted all neuronal profiles in all fascicles in each section. The number of fibers was then divided by the spiral extent (in millimeters) of osseous spiral lamina included in that section, to arrive at an estimate of the number of myelinated fibers per millimeter of organ of Corti. For the final plots, all fiber densities thus derived were normalized by placematched data from control ears and expressed as a fractional loss.

Immunocytochemistry and LacZ histochemistry. Mice were anesthetized and fixed by intracardiac perfusion with $4 \%$ paraformaldehyde (PFA) in PBS for NRG1 and erbB receptor stainings, with 3\% PFA in PBS for DN-erbB4 staining, or with Bouin's fixative for neurofilament staining. Inner ears were dissected out, and tissue was fixed by intralabyrinthine perfusion and postfixed overnight (at $4^{\circ} \mathrm{C}$ ) for NRG1, erbB receptor, and neurofilament staining or for $10 \mathrm{~min}$ for $\mathrm{DN}$-erbB4 staining in the same fixatives. Tissues for neurofilament staining were further fixed in $10 \%$ formalin for $1 \mathrm{~d}$ at $4^{\circ} \mathrm{C}$.

For immunostaining, inner ears were decalcified, embedded in OCT (Sakura, Finetek, Torrance, CA), and cryosectioned at $14 \mu \mathrm{m}$. For staining with anti-NRG or anti-erbB receptor antibodies, sections were blocked with 3\% BSA, $0.1 \%$ Triton X-100 in PBS for $1 \mathrm{hr}$ at room temperature, followed by incubation with primary antibodies diluted in blocking solution at $4^{\circ} \mathrm{C}$ overnight. For staining with antibodies that recognize DN-erbB4 or anti-neurofilament 200 antibodies, sections were blocked with 5\% normal horse serum (NHS) in PBS for 30 min, followed by incubation with primary antibody diluted in PBS with $1 \%$ NHS at $4^{\circ} \mathrm{C}$ overnight. Sections were washed with PBS, and detection was performed either using the appropriate fluorescent secondary antibodies (Cy3conjugated antibodies from Jackson ImmunoResearch Laboratories) for $1 \mathrm{hr}$ at room temperature or using a secondary biotinylated donkey antimouse antibody followed by the ABC reagent (Vector Laboratories, Burlingame, $\mathrm{CA}$ ) and $\mathrm{DAB} / \mathrm{H}_{2} \mathrm{O}_{2}$. For immunofluorescence, sections without antibodies were examined and found to have no significant autofluorescence. The following primary antibodies were used: rabbit anti-erbB2 polyclonal (Santa Cruz Biotechnology, Santa Cruz, CA; 1:4000), rabbit anti-erbB3 polyclonal (Santa Cruz; 1:1000), mouse antierbB4 monoclonal (H4.77.16; NeoMarkers; 1:250), rabbit antiNRG1polyclonal (Santa Cruz; 1:1000), or mouse anti-neurofilament 200 $\mathrm{kDa}$ monoclonal antibody (clone R-3; 1:100,000). Nuclei were stained with Hoechst 33342 (Molecular Probes, Eugene, OR).

For LacZ staining, fixed tissue was incubated overnight at $24^{\circ} \mathrm{C}$ in a staining solution [10 mm TrisCl, $\mathrm{pH} 1.7,1 \mathrm{~mm} \mathrm{~K} \mathrm{~K}_{4} \mathrm{Fe}(\mathrm{CN})_{6} \cdot{ }^{3} \mathrm{H}_{2} \mathrm{O}, 1 \mathrm{~mm}$ $\mathrm{K}_{3} \mathrm{Fe}(\mathrm{CN})_{6}, 2 \mathrm{~mm} \mathrm{MgCl}_{2} \cdot 6 \mathrm{H}_{2} \mathrm{O}, 0.02 \% \mathrm{NP}-40,0.01 \%$ sodium deoxycholate, and $1 \mathrm{mg} / \mathrm{ml} \mathrm{X-gal],} \mathrm{washed} \mathrm{in} \mathrm{PBS,} \mathrm{postfixed} \mathrm{in} \mathrm{4 \%} \mathrm{PFA} \mathrm{over-}$ night at $4^{\circ} \mathrm{C}$, and decalcified in EDTA. After staining, the tissue was rapidly dehydrated, embedded in Araldite, and sectioned at $40 \mu \mathrm{m}$.

In situ hybridization. In situ hybridization was performed on $15 \mu \mathrm{m}$ cochlear cryosections captured onto positively charged microscope slides (Superfrost Plus, Fisher Scientific). Tissue sections were stored at $-80^{\circ} \mathrm{C}$ until used. After bringing them to room temperature, sections were fixed 

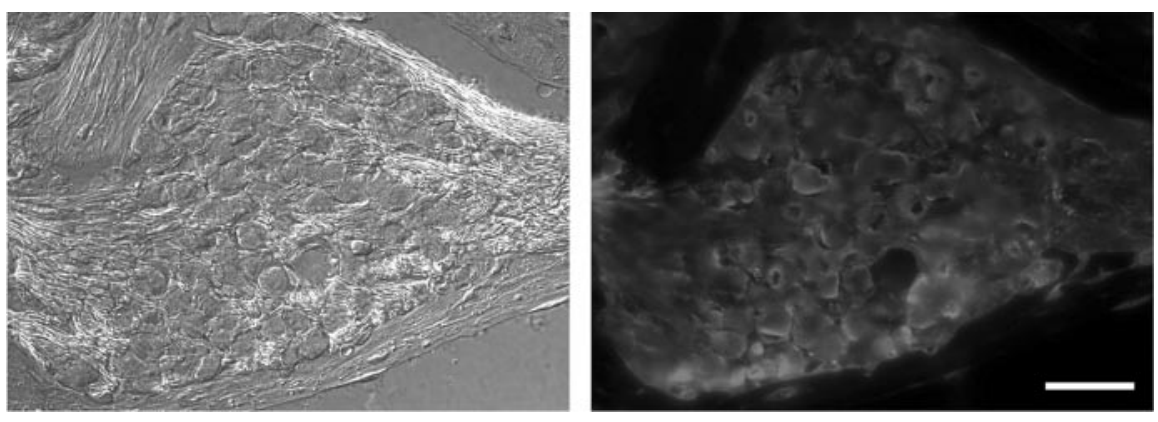

Figure 1. Spiral ganglion cells in the cochlea express NRG1. Right panel, Section of the spiral ganglion from upper basal turn stained with anti-NRG1 antibodies. Left panel, The same section as seen under DIC optics. Scale bar, $50 \mu \mathrm{m}$.

in fresh, ice-cold $4 \%$ paraformaldehyde in $0.1 \mathrm{~m}$ PBS for $15 \mathrm{~min}$, rinsed three times for $5 \mathrm{~min}$ in PBS, acetylated in $0.1 \mathrm{M}$ triethanolamine/acetic anhydride for $10 \mathrm{~min}$, and rinsed twice in PBS and once in $2 \times$ salinesodium citrate buffer (SSC) for 5 min each before they were submerged in slide mailers in hybridization buffer [ $50 \%$ formamide (Life Technologies, Gaithersburg, MD), $5 \times$ SSC, $2 \%$ blocking reagent (Boehringer, Mannheim, Germany), $0.1 \%$ SDS, and $0.02 \% N$-laurylsarcosine] for 2 $\mathrm{hr}$. Sense and antisense digoxigenin-labeled cRNA probes (nucleotides 34-1874 from the human erbB4 receptor; accession number NM_005235) were boiled in $20 \mathrm{ml}$ of hybridization buffer for $2 \mathrm{~min}$ and added to the slide mailers. Probe concentrations approximated $100 \mathrm{ng} /$ $\mathrm{ml}$. Hybridization proceeded in the mailers overnight at $70^{\circ} \mathrm{C}$. Slides were then rinsed three times in $2 \times$ SSC and washed twice in $0.2 \times$ SSC for $30 \mathrm{~min}$, all at $70^{\circ} \mathrm{C}$. Subsequently, sections were blocked in $0.1 \mathrm{~m}$ maleate buffer, $\mathrm{pH} 7.0$, containing $1 \%$ blocking reagent for $1 \mathrm{hr}$ at room temperature and then incubated in sheep anti-DIG-Fab fragments conjugated to alkaline phosphatase $(0.15 \mathrm{U} / \mathrm{ml}$; Boehringer) in maleate/blocking buffer for $1 \mathrm{hr}$. After several rinses over $1 \mathrm{hr}$ in maleate and one quick rinse in 0.1 м Tris, $0.15 \mathrm{M} \mathrm{NaCl}, \mathrm{pH}$ 9.5, slides were placed upside down onto a tray and developed in the dark in substrate solution, $\mathrm{pH} 9.5$, containing $0.1 \mathrm{M}$ Tris, $0.15 \mathrm{M} \mathrm{NaCl}, 50 \mathrm{~mm} \mathrm{MgCl}$, 1 mm levamisole, $0.4 \mathrm{~mm}$ 5-bromo-4 chloro-indolylphosphate, and $0.4 \mathrm{~mm}$ nitroblue tetrazolium chloride (both from Boehringer). The development was stopped by incubation in 10 mм Tris, 25 mm EDTA, pH 8.0. Slides were quickly rinsed in water and then coverslipped with Vectashield (Vector Laboratories).

Evaluation of cochlear function. Auditory brain-stem evoked response $(\mathrm{ABR})$ and distortion-product otoacoustic emission (DPOAE) were recorded from mice anesthetized with xylazine and ketamine. For ABR, needle electrodes were inserted at vertex, pinna, and back, and $5 \mathrm{msec}$ tone pips ( $0.5 \mathrm{msec}$ rise-fall, with a $\cos ^{2}$ envelope, at $\left.35 / \mathrm{sec}\right)$ were presented to the eardrum. The response was amplified (10,000 times), filtered $(0.1-3 \mathrm{kHz})$, and averaged with an analog-to-digital board in a PC-based data-acquisition system. Sound level was raised in $5 \mathrm{~dB}$ steps from 0 to $90 \mathrm{~dB}$ sound pressure level (SPL). At each level, 1024 responses were averaged (with stimulus polarity alternated) after "artifact rejection." Threshold was determined by visual inspection.

The DPOAE in response to two primary tones of frequency $\mathrm{f} 1$ and $\mathrm{f} 2$ were recorded at $2 \mathrm{f} 1-\mathrm{f} 2$, with $\mathrm{f} 2 / \mathrm{f} 1=1.2$ and the $\mathrm{f} 2$ level $10 \mathrm{~dB}$ lower than the f1 level. Measurements were performed using an ER-10C (Etymotics Research) acoustic system consisting of two sound sources and one microphone. Ear-canal sound pressure was amplified and digitally sampled at $4 \mu \mathrm{sec}$ intervals. Fast Fourier transforms (FFTs) were computed from averaged waveforms of ear-canal sound pressure, and the DPOAE amplitude was extracted at 2f1-f2. The noise floor was also measured, defined as the average of six points in the FFT on either side of the 2f1-f2 frequency and surrounding noise floor. Iso-response contours were interpolated from plots of amplitude versus sound level, performed in $5 \mathrm{~dB}$ steps of $\mathrm{f} 1$ level. Threshold was defined as the $\mathrm{f} 1$ level required to produce a DPOAE at $0 \mathrm{~dB}$ SPL.

Real-time quantitative RT-PCR. Real-time quantitative RT-PCR (rtRT-qPCR) was performed as in Stankovic and Corfas (2003). Briefly, P26 mice were killed in a $\mathrm{CO}_{2}$ chamber, inner ears were extracted, cochlear membranous labyrinths were dissected from otic capsule in RNAlater
(Ambion, Austin, TX), and total RNA was purified using RNeasy spin-columns (Qiagen, Valencia, CA). Total RNA was treated with RNasefree DNase both on column (Qiagen) and off column (RNase-free DNase I kit; Invitrogen, Carlsbad, CA). Two cochleas from an animal were processed as one sample. Only RNA samples that fulfilled the criteria that we established previously (Stankovic and Corfas, 2003), i.e., the samples that were not degraded (as assessed by Agilent 2100 bioanalyzer) and not contaminated with genomic DNA [as assessed by conventional PCR with glyceraldehyde-3phosphate dehydrogenase (GAPDH) primers, followed by gel electrophoresis], were used for cDNA synthesis using Omniscript (Qiagen). For a $20 \mu \mathrm{l}$ reaction, we used $2 \mu \mathrm{l}$ of $10 \times \mathrm{RT}$ buffer, $0.5 \mathrm{~mm}$ each dNTP, $1.5 \mu \mathrm{M}$ random hexamers, $10 \mathrm{U}$ RNase inhibitor (Invitrogen), $4 \mathrm{U}$ Omniscript reverse transcriptase, $1 \mu \mathrm{l}$ of RNasefree water, and $10 \mu \mathrm{l}$ of sample RNA. Reverse transcription was performed at $37^{\circ} \mathrm{C}$ for $1 \mathrm{hr}$, followed by $93^{\circ} \mathrm{C}$ for $5 \mathrm{~min}$ and then rapid cooling on ice. Samples without reverse transcriptase ("No-RT") were processed in parallel and served as negative controls. Measurements were made with an iCycler machine (Bio-Rad, Hercules, CA) and QuantiTect SYBR Green PCR kit (Qiagen). For each well of the 96-well rt-RT-qPCR plate (Bio-Rad), the $25 \mu \mathrm{l}$ reaction contained $12.5 \mu \mathrm{l}$ of $2 \times$ QuantiTect SYBR Green PCR Master Mix, $0.5 \mu \mathrm{M}$ each forward and reverse primer, $7.5 \mu \mathrm{l}$ of RNase-free $\mathrm{H}_{2} \mathrm{O}$, and $2.5 \mu \mathrm{l}$ cDNA template. The cycling conditions were as follows: $95^{\circ} \mathrm{C}$ for $15 \mathrm{~min}$ followed by 50 cycles of $94^{\circ} \mathrm{C}$ for $30 \mathrm{sec}, 54^{\circ} \mathrm{C}$ for $30 \mathrm{sec}$, and $72^{\circ} \mathrm{C}$ for $60 \mathrm{sec}$. Each sample was loaded in quadruplicate, and each rt-RT-qPCR plate was used to test expression of a single gene.

The characterization and sequence of the primers for $18 \mathrm{~S}$ rRNA, NT3, BDNF, and GDNF were as described in Stankovic and Corfas (2003). A total of 12 wild-type mice and 12 GFAP-DN-erbB4 homozygous mice were used.

\section{Results}

\section{Pattern of expression of NRG1 and erbB receptors in the}

\section{postnatal murine cochlea}

To gain insight into the roles of NRG1-erbB signaling in cell-cell interactions within the mature cochlea, we mapped the pattern of expression of NRG1 and the erbB receptors by immunostaining. As suggested by previous in situ hybridization studies (Morley, 1998), NRG1 antibodies clearly labeled SGNs (Fig. 1). In contrast, strong immunostaining for erbB2 and erbB3 was observed in supporting cells within the organ of Corti, in particular in the cells around the inner hair cells (IHCs) (inner border and inner phalangeal cells) and the supporting cells beneath the outer hair cells (OHCs) (Deiters cells), as well as in the pillar cells, the Boettcher cells, and the inner sulcus cells (Fig. 2). Surprisingly, immunostaining for erbB2 and erbB3 in these supporting cells was stronger than that observed in Schwann cells, which are known to express erbB receptors and to respond to NRG (Cohen et al., 1992; Meyer and Birchmeier, 1995). The IHCs showed immunoreactivity for erbB2 but not erbB3, whereas OHCs had no immunoreactivity for either receptor. No erbB4 immunoreactivity was detected in any cochlear cell type (data not shown). These results suggest that NRG1-erbB signaling may mediate interactions between SGNs and supporting cells in the organ of Corti and/or Schwann cells. Because the IHCs expressed only erbB2, these cells are unlikely to respond to NRG (see below).

\section{Cochlear expression of a dominant-negative erbB4 under the control of the GFAP promoter}

Most mice lacking the genes for erbB receptors or NRG1 die during embryonic development or perinatally (Gassmann et al., 
1995; Lee et al., 1995; Meyer and Birchmeier, 1995; Erickson et al., 1997; Riethmacher et al., 1997). Therefore, these mutant lines are not useful to study NRGerbB signaling in the postnatal cochlea; however, cell-specific ablation of erbB signaling can be informative. We have created transgenic mice expressing a dominant-negative erbB4 receptor under the control of the GFAP promoter (GFAP$\mathrm{DN}$-erbB4 mice) to study the roles of NRG1-erbB signaling in interactions between neurons and astrocytes in the hypothalamus (Prevot et al., 2003) and between peripheral unmyelinated sensory axons and nonmyelinating Schwann cells in the sciatic nerve (Chen et al., 2003). The dominant-negative receptor is a truncated form of the human erbB4, lacking much of the intracellular domain of this tyrosine kinase receptor. Expression of DN-erbB4 blocks the ligand-induced activation of erbB2, erbB3, and erbB4 without affecting signaling through erbB1, which is the EGF receptor (Prevot et al., 2003).

Because the cochlear supporting cells that express erbB2 and erbB3 receptors (see above) also express GFAP (Rio et al., 2002), we tested for cochlear expression of the DN-erbB4 in mouse lines that express the transgene in the peripheral nervous system under the control of the GFAP promoter (Chen et al., 2003). RT-PCR and Western blot analysis showed that DNerbB4 is indeed expressed in the cochlea when driven by the GFAP promoter in this transgenic line (Fig. 3A, B). In situ hybridization showed that DN-erbB4 mRNA is expressed by supporting cells in the IHC area, Deiters cells, and inner sulcus cells of GFAP-DN-erbB4 mice (Fig. 3C, left panel). No DN-erbB4 expression was found in hair cells or pillar cells of transgenic mice (Fig. 3C, left panel) or any cell of wild-type cochlear tissue (Fig. 3, right panel). Schwann cells in the osseous spiral lamina showed lower levels of DN-erbB4 mRNA expression, in agreement with the low levels of GFAP that these cells express (Rio et al., 2002). Finally, immunostaining with antibodies against the extracellular domain of the human erbB4 showed that DN-erbB4 immunoreactivity is localized to supporting cells in IHC and $\mathrm{OHC}$ areas of transgenic mice but is absent in tissues derived from wild-type mice (Fig. 3D).

Together, these results suggest that NRG1-erbB signaling in the cochlea of GFAP-DN-erbB4 mice is likely to be defective. Because high levels of transgene expression are required to completely block the function of the wild-type erbB receptors (Chen et al., 2003), we studied the phenotype of mice carrying two copies of the transgene (homozygous) and compared them with animals with one copy (hemizygous) and with wild types. Importantly, immunostaining with erbB2 and erbB3 antibodies showed no alterations in the expression of wild-type receptors in the supporting cells of mutant mice (data not shown), suggesting that any alteration found in the transgenic mice should be attributed to functional blockade of the wild-type receptors rather than to complex feedback loops.

\section{DN-erbB4 expression results in profound cochlear dysfunction}

To determine whether DN-erbB4 expression affects hearing, we compared cochlear function in wild-type and transgenic mice by measuring ABRs, compound action potentials (CAPs), and/or DPOAEs (Fig. 4). Measurements of ABR thresholds in a first cohort of homozygous transgenic mice showed that all animals $(n=6)$ displayed elevated thresholds indicative of hearing loss 

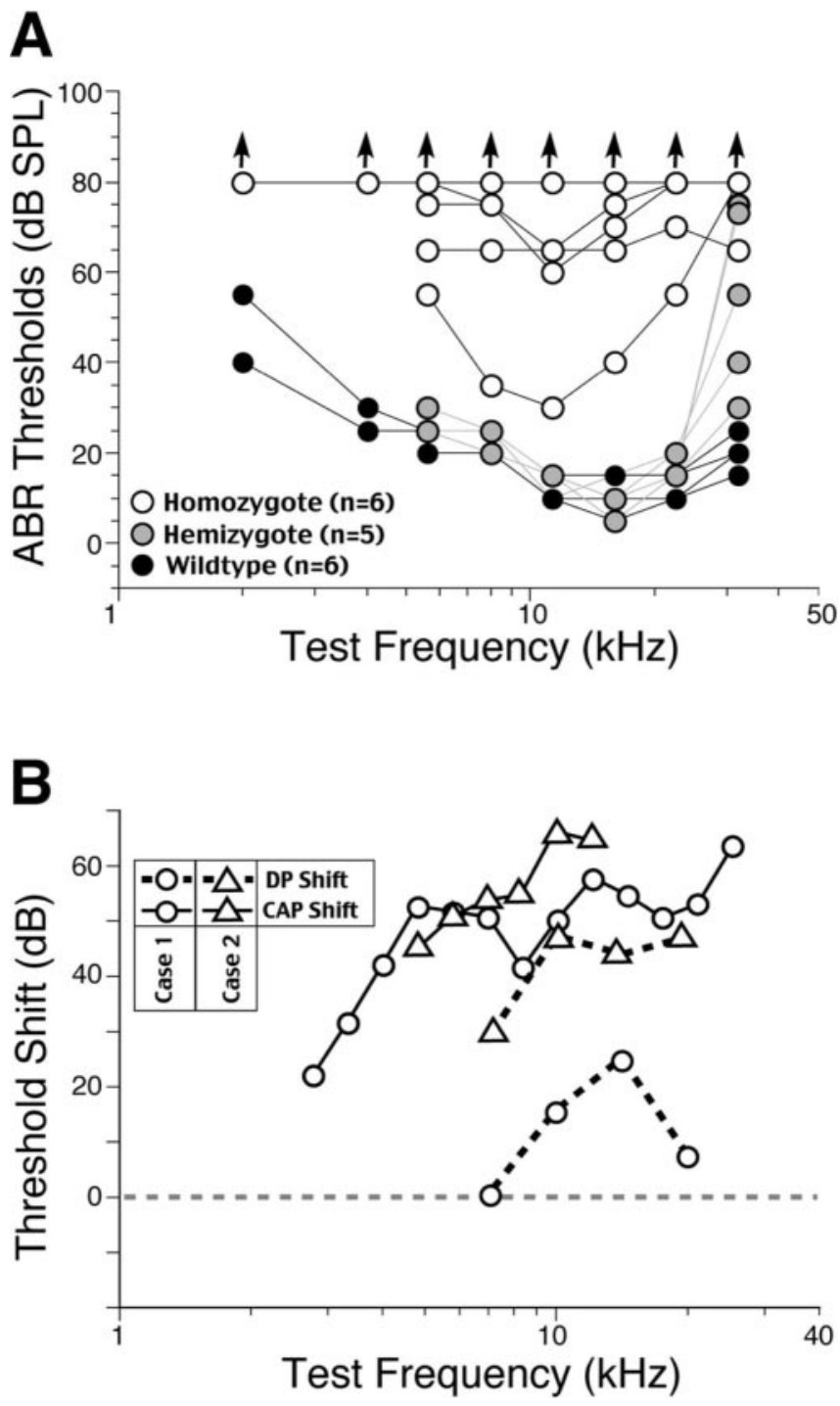

Figure 4. Cochlear neural output is reduced in homozygote transgenic mice, although outer hair cell function can be nearly normal. $A$, ABR thresholds for a cohort of mice including six wild-type, five hemizygote, and six homozygote ears. Homozygotes and wild types ranged in age from 31 to $149 \mathrm{~d}$; hemizygotes were tested at $138 \mathrm{~d}$. Arrows at $80 \mathrm{~dB}$ indicate that, for several homozygotes, there was no response at the highest sound levels tested. $B$, Comparison of cochlear neural output (assayed by shift in CAP thresholds) versus OHC function (assayed by shift in DPOAE threshold) for two selected homozygote cases. Threshold shifts were computed by averaging the CAP and DPOAE thresholds in the wild-type animals and then subtracting CAP and DPOAE thresholds in each ear from these mean values.

(Fig. 4A). There was some heterogeneity in the degree of dysfunction, with threshold shift ranging from as little as $20-40 \mathrm{~dB}$ in the least affected animal to at least $60-80 \mathrm{~dB}$ in the most affected animals (which were nonresponsive at the highest tested levels). This heterogeneity was not correlated with age, which ranged from 31 to $149 \mathrm{~d}$ in this first cohort; the homozygote with the best thresholds was actually one of the oldest animals. The ABR responses in an age-matched set of hemizygous animals $(n=5)$ were indistinguishable from wild type, except at the highest test frequency, where there was threshold elevation of as much as 60 $\mathrm{dB}$. It may be significant, in this regard, that GFAP expression in supporting cells is normally highest in the basal turn (Rio et al., 2002), where these high-frequency responses are generated. Thus, higher levels of DN-erbB4 expression in the basal turn of the hemizygous mice may be sufficient to block erbB signaling in cells with only one copy of the transgene.

In a second cohort of animals (two wild types and two homozygotes, aged 68-72 d), we measured CAPs from the cochlea to get a more accurate measure of the cochlear neural output and compared these responses with DPOAEs from the same ears: DPOAEs provide information about $\mathrm{OHC}$ function and allow us to differentiate between the dysfunction occurring upstream from downstream of afferent synaptic transmission. In both homozygous animals, the CAP measures showed large-threshold elevation $(40-60 \mathrm{~dB})$ across most test frequencies, consistent with a profound decrease in sound-driven neural activity (Fig. $4 B$, solid lines). Threshold shifts are computed by comparing the thresholds measured in each animal with the mean values for wild types at the same test frequency.

Despite the profound elevation of neural thresholds, one of the two homozygous cases had almost normal DPOAE responses (threshold shifts $<20 \mathrm{~dB}$ ), consistent with normal OHC function, whereas the other was more affected (threshold shifts $>40$ dB) (Fig. $4 B$, dashed lines). The former pattern of loss is expected when the hearing loss is dominated by neural dysfunction.

Despite the profound elevation of neural thresholds, the minimum latency of CAP responses in the transgenic animals was also close to normal: $1.38 \mathrm{msec}$ in the transgenic with strong residual DPOAEs versus $1.32 \mathrm{msec}$ in a wild type. The normality of neural response latency in the transgenic animals suggests a normal conduction velocity. This, in turn, is consistent with the notion that peripheral Schwann cells are intact despite loss of cochlear neurons (see below).

GFAP-DN-erbB4 transgenics show postnatal degeneration of cochlear neurons without concomitant hair cell loss

To define the structural basis for hearing loss in transgenic animals, we analyzed cochlear histopathology by light microscopy in both adult and neonatal ears via a number of histological techniques. In the adult, the most striking and consistent histopathology in homozygote transgenics was the loss of the majority of cochlear afferent neurons throughout the cochlear spiral. This loss was diffuse and evenly distributed, with no obvious gradient from base to apex. Representative sections through the upper basal turn are shown in Figure 5, $A$ and $B$. Note the relatively small number of neuronal cell bodies (filled arrow) in the homozygote $(B)$ compared with the wild type $(A)$ at the same cochlear region. The neuronal loss seen in the homozygous transgenic animals was not accompanied by a comparable degree of hair cell loss. In neonatal ears, as shown by the micrographs in Figure 5, $C$ and $D$, neuronal density appeared normal in the spiral ganglion of transgenic animals.

The spiral ganglion contains two classes of afferent neurons: a majority ( $~ 90 \%)$ population of type I cells synapsing with IHCs and a minority $(\sim 10 \%)$ population of type II cells synapsing on OHCs. To determine which cell type was most affected in transgenics, we used antibodies against the $200 \mathrm{kDa}$ subunit of the neurofilament protein (NF200), which is expressed only at high levels in type II somata (Berglund and Ryugo, 1991). Qualitative analysis showed that the number of NF200-stained somata in the ganglia of homozygous mice (Fig. $5 \mathrm{H}$ ) was similar to that in wild types (Fig. $5 G$ ), although the total number of neurons in the mutant was reduced dramatically (Fig. $5 E, F$ ). Thus, it appears that only type I neurons are lost in transgenic cochleas.

To quantify the relation between hair cell and neuronal loss, as well as its time course, full hair cell counts and sample neuronal counts were performed in several ears from wild-type, hemizy- 

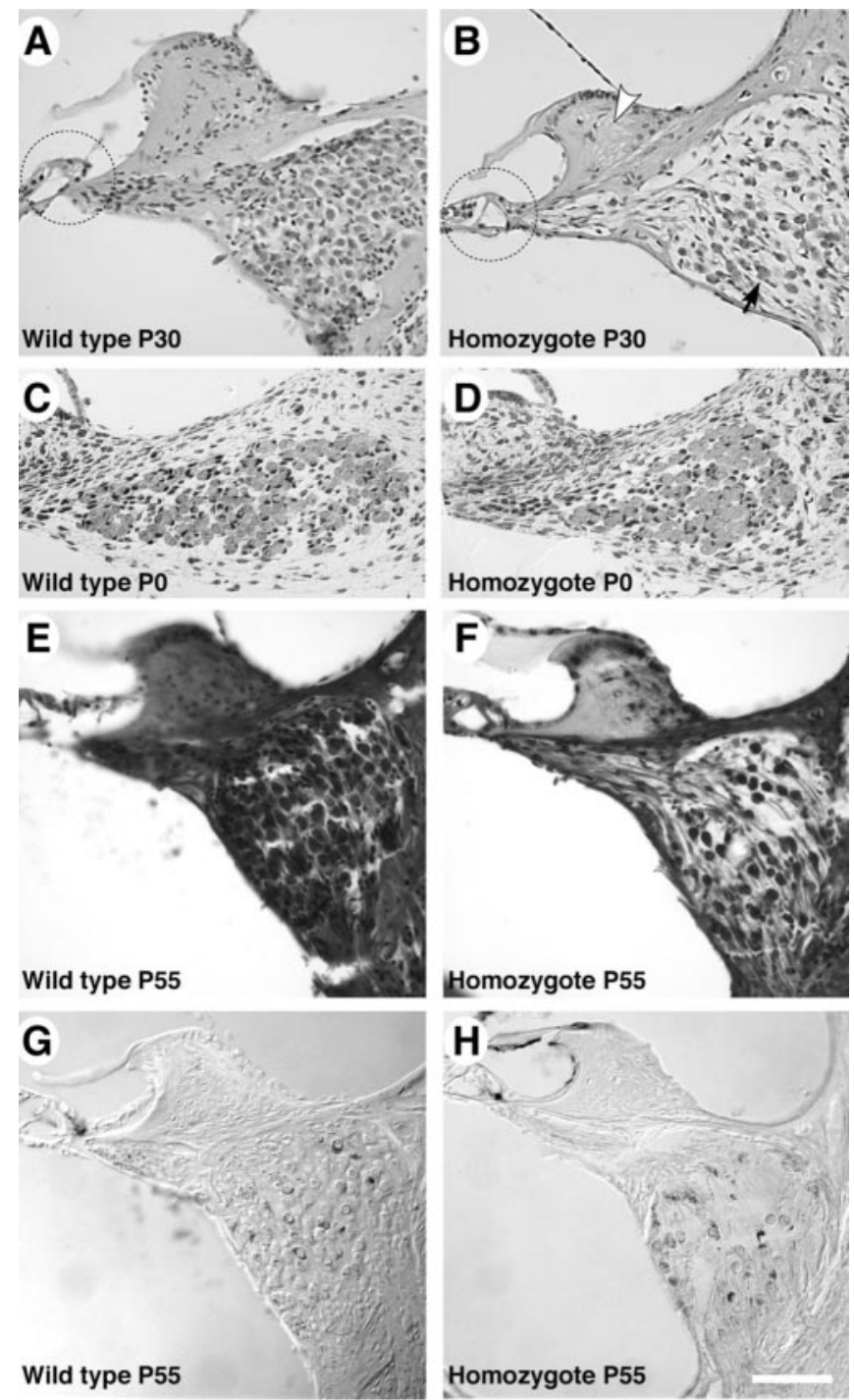

Figure 5. Transgenic cochleas show postnatal primary degeneration of auditory nerve fibers without loss of hair cells. $A, B$, Sections through the upper basal turn of a wild-type $(A)$ and homozygote $(B)$ cochlea at $\mathrm{P} 30$. According to the cochlear frequency map for mouse (see Materials and Methods), this cochlear region mediates threshold response to $\sim 18 \mathrm{kHz}$, approximately the region of maximum normal sensitivity. Most SGNs have degenerated ( $B$, black arrow points to one of the remaining neurons) without loss of hair cells (dotted circles). Degeneration of fibrocytes in the limbus ( $B$, open arrowhead) is also visible in the transgenic cochlea. $C, D$, Sections through the upper basal turn at $P O$ reveal no obvious decrease in density of $S G N$ s in the ear of homozygous mice $(D)$ compared with the wild type. $E$, $F$, Sections through the upper basal turn of a wild-type $(E)$ and homozygote $(F)$ cochlea at P55 show degeneration similar to that observed at P30. G, H, Sections adjacent to those in $E$ and $F$ stained with anti-NF200 antibodies show similar number of profiles of type II SGNs, indicating that neuronal degeneration is restricted to type I neurons. Scale bar, $100 \mu \mathrm{m}$.

gous, and homozygous transgenics at a number of postnatal ages. Consistent hair cell loss was seen only in the extreme basal (highfrequency) region of the ears (Fig. 6). Throughout the rest of the cochlear spiral, many homozygotes showed minimal loss of either IHCs or OHCs and most showed $<20 \%$ loss. These observations suggest that the loss of hair cells is unlikely to be a direct result of DN-erbB4 expression.

Peripheral axon counts were made in tangential sections through the osseous spiral lamina (Fig. $7 A, B$ ) at three cochlear locations (Fig. 6A, shaded regions). As illustrated in Figure 7A (inset), this tangential section plane captures the peripheral ax-
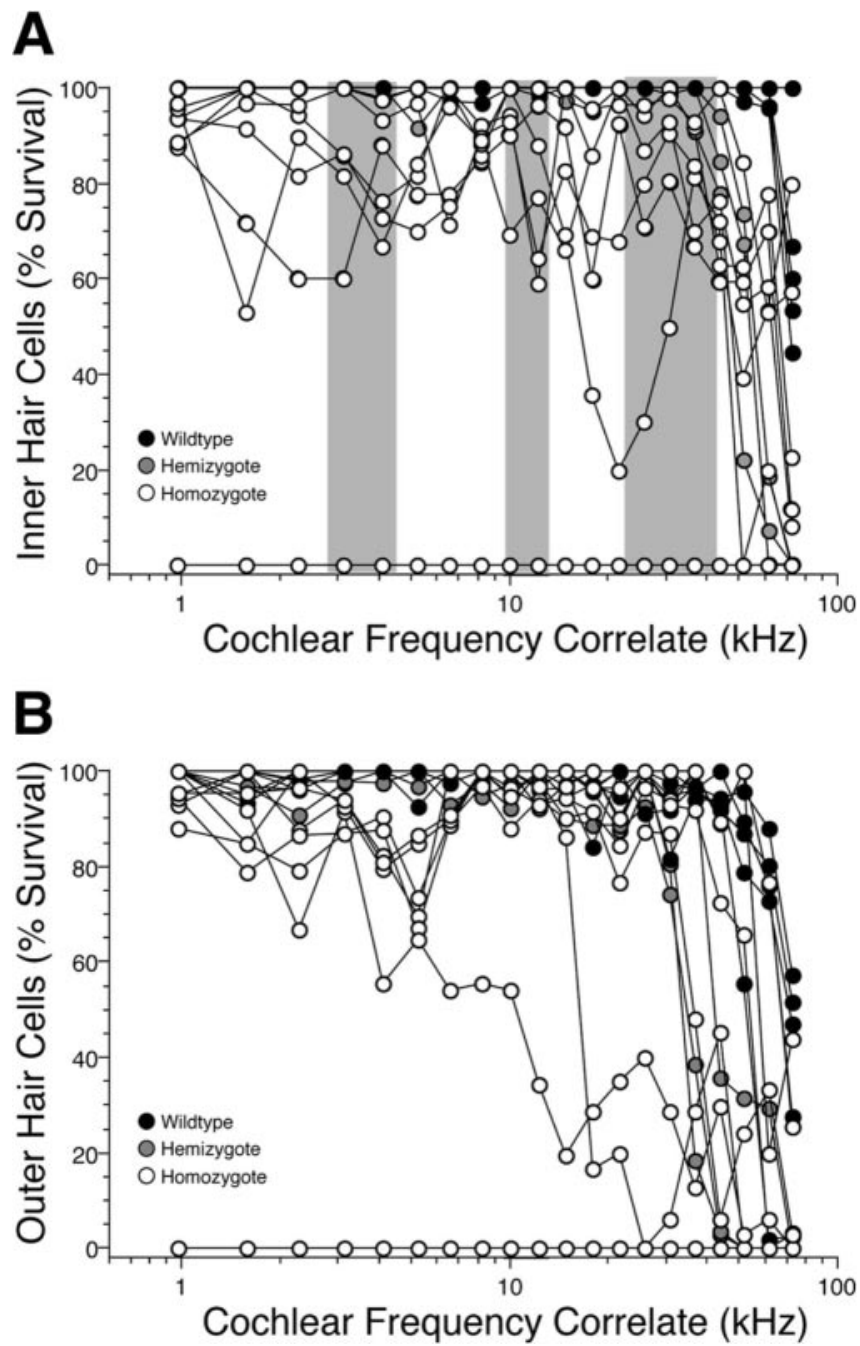

Figure 6. Hair cell loss in transgenics is minimal in regions outside the extreme highfrequency region. Hair cell counts for a randomly selected subset of the animals from which ABRs were obtained (Fig. $4 A$ ). $A$, IHC counts. $B$, Counts of first-row OHCs. Other OHC rows showed a similar pattern of loss as the first row. The shaded frequency regions shown in $A$ correspond to the cochlear regions cut in tangential section in which neuronal counts were made (Fig. 7).

ons of cochlear afferents in cross section as they travel from hair cells to their cell bodies in the spiral ganglion. This quantitative analysis showed that axonal density decreased postnatally in homozygous transgenics (Fig. 7C). In contrast, no significant change in axonal number was seen in hemizygotes, even at $>200$ $\mathrm{d}$ of age. As late as P10, axonal density was still normal in homozygotes. By P20, however, massive loss $(\sim 80 \%)$ of the peripheral axons had taken place. At this time, no hair cell degeneration was seen, and the somata of the cochlear afferents remained intact. At the oldest homozygote ages investigated $(\sim 120 \mathrm{~d})$, there was no further change in peripheral axon counts compared with 90-d-old homozygotes; however, the somatic loss increased to match the axonal loss (data not shown). There was significant heterogeneity in the progression of hair cell loss in homozygotes from 20 to $90 \mathrm{~d}$ of age. One $90 \mathrm{~d}$ case showed near complete loss of IHCs and OHCs, whereas two other cases showed only $\sim 10 \%$ loss. Data in Figure 7 are from the upper basal turn (Fig. 6A, middle gray zone); similar results were obtained in both lower basal and apical turns of the cochlea [(Fig. 6A) cochlear regions 

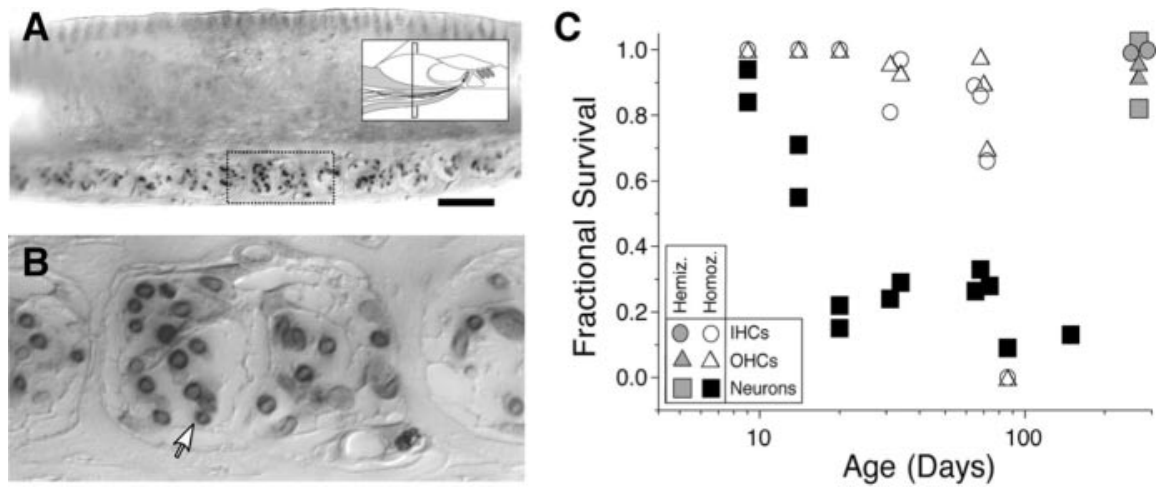

Figure 7. Peripheral axons of auditory nerve fibers in homozygous mice degenerate between P10 and P20. A, Photomicrograph of a tangential section (inset) through the osseous spiral lamina in the basal turn of a homozygote cochlea aged $68 \mathrm{~d}$. Scale bar, 50 $\mu \mathrm{m} . B$, Higher magnification of the region in $A$ indicated by the dotted box. C, Fractional survival of peripheral axons and hair cells obtained from 13 homozygote, 3 heterozygote, and 5 wild-type cochleas. Fractional survival is defined as the ratio of counts obtained in the transgenics to the mean value from the five wild types. All data are from the upper basal turn, i.e., the cochlear region corresponding to $\sim 18 \mathrm{kHz}$ (Fig. 6, middle gray box).

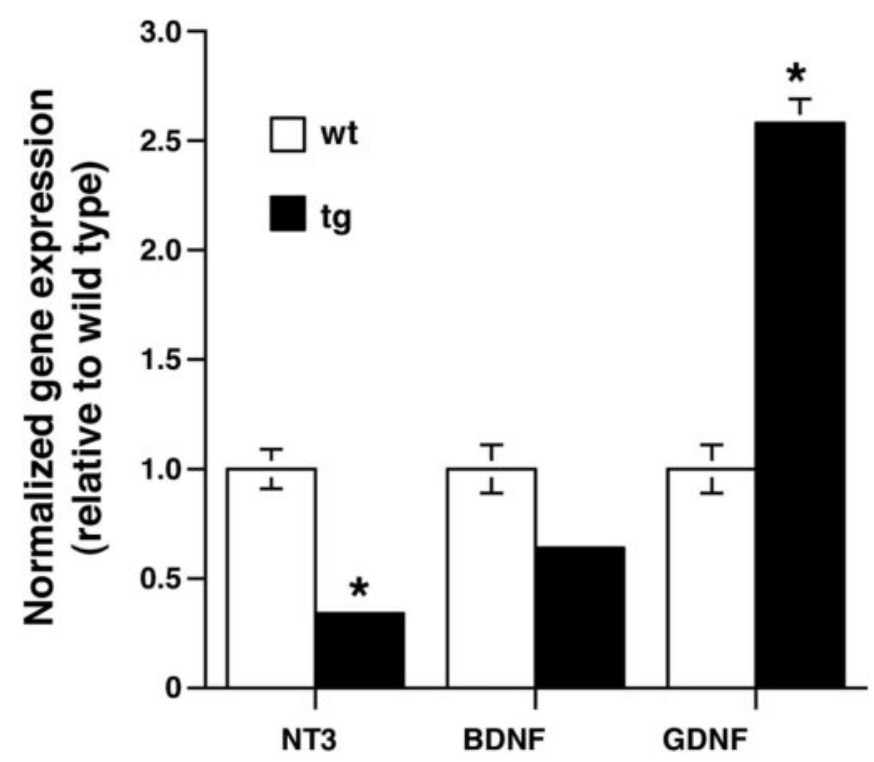

Figure 8. NT3 expression of gene is decreased and GDNF expression is increased in the cochleas of homozygous transgenic mice. The level of expression of NT3, BDNF, and GDNF in the cochleas of P26 homozygous mice $(n=12)$ was compared with those in P26 wild types $(n=$ 12) by real-time quantitative $R T-P C R .{ }^{*} p<0.01$.

indicated by apical-most and basal-most regions of gray shading; data not shown]. Careful analysis of toluidine blue-stained $2 \mu \mathrm{m}$ sections through the osseous spiral lamina showed no signs of Schwann cell degeneration during the time of maximal degeneration of the peripheral axons of cochlear neurons (data not shown).

Histopathology in homozygote transgenics was sometimes observed in fibrocytes of the spiral limbus and the spiral ligament (Fig. $5 B$, open arrowhead). The heterogeneity in degree of damage to these accessory structures was correlated with the heterogeneity in the DPOAE responses discussed above: the one homozygote case with the strongest DPOAE responses (Fig. $4 \mathrm{~B}$ ) was also the histological case with the least fibrocyte degeneration. These changes in fibrocytes appeared only at ages $>20 \mathrm{~d}$, i.e., after the loss of SGN peripheral axons was already pronounced.
GFAP-DN-erbB4 transgenic mice have reduced expression of NT3

The sudden and catastrophic death of the SGNs in the transgenic mice in the absence of hair cell loss or Schwann cell degeneration suggested that the neuronal loss was the primary degenerative event in this cascade and that disruption of signaling between the neurons and supporting cells within the sensory epithelium could be the underlying cause. SGNs have been shown to depend on neurotrophic factors, in particular the neurotrophins BDNF and NT3, for their survival during development (for review, see Fritzsch et al., 1999). Moreover, GDNF has been proposed to be neuroprotective for injured SGNs (Altschuler et al., 1999; Yagi et al., 2000). Therefore, we compared the relative levels of expression of BDNF, NT3, and GDNF in the cochlea of P26 wild-type and homozygous transgenic mice using real-time quantitative RT-PCR (Stankovic and Corfas, 2003) (Fig. 8). The expression of NT3 gene was decreased by $2.9 \pm 0.2$-fold in cochleas of homozygous mice as compared with wild type $(p=0.01)$. BDNF expression in the cochlea of mutant mice was somewhat lower, although not to a statistically significant degree $(p=0.08)$ in the metric that we used. Interestingly, in the cochleas of DN-erbB4 homozygous mice, there was a $2.6 \pm 0.1$-fold increase in expression of GDNF ( $p=0.007)$ as compared with wild type, indicating that the reduction in NT3 was specific.

The NT3 promoter directs expression to hair cells and supporting cells in the adult cochlea

The results described above suggest that NRG-erbB receptor mediates reciprocal interactions between SGNs and supporting cells of the organ of Corti that involve the control of NT3 expression. Therefore, understanding the pattern of NT3 expression in the adult cochlea is important to formulate a model of NRG-erbB signaling in the cochlea. Most studies of NT3 expression were performed on the developing inner ear and point to both the hair cells and supporting cells around them as expressing NT3 (Fritzsch et al., 1999; Qun et al., 1999); however, the expression of NT3 in the adult cochlea is not universally agreed on. Some studies report NT3 expression by adult hair cells only (Fritzsch et al., 1999), whereas others also describe NT3 in the supporting cells in the early postnatal period (Qun et al., 1999; Pirvola et al. 1992). To analyze the pattern of expression of NT3 in the cochlea at the time at which neuronal degeneration occurs in the transgenic mice described in this paper, we analyzed the cochlea of mice in which the Escherichia coli lacZ gene is integrated into the neurotrophin-3 locus (Farinas et al., 1994). In this mouse strain, cells that normally express NT3 also express $\beta$-galactosidase, allowing for their visualization and identification by histochemical staining (Fritzsch et al., 1997). Histological analysis of LacZ staining showed that, in the P26 cochlea, NT3 is most highly expressed in the IHC area, with similar levels of expression in IHCs and their supporting cells (Fig. 9). We did not find significant levels of NT3 expression by Schwann cells of the auditory nerve.

\section{Discussion}

This study provides evidence that supporting cells of the organ of Corti are key players in the survival of afferent neurons in the 
adult cochlea and that this survival depends on erbB signaling. First, in the transgenic mouse line studied here, expression of dominant-negative erbB receptors in the inner ear leads to a primary neuropathy phenotype, i.e., the postnatal degeneration of the myelinated (type I) sensory neurons of the cochlea without concomitant loss of the cochlear (inner) hair cells that they innervate (Figs. 5-7). This shows that normal erbB signaling is necessary for the long-term survival of adult SGNs. Second, as expected from the pattern of GFAP expression in the cochlea (Rio et al., 2002), expression of DN-erbB4 in the organ of Corti under the control of the GFAP promoter is restricted to supporting cells (Fig. 3), where it should block

the function of wild-type erbB receptors (Fig. 2). These results indicate that supporting cells are the locus where erbB signaling is required to promote SGN survival. The axons of type I cochlear afferents are myelinated, and myelinating Schwann cells do not express significant levels of GFAP (Jessen et al., 1990). Thus, it is unlikely that Schwann cells are involved in the observed phenotype. The present study, together with previous reports on human temporal bones (Johnsson, 1974; Schuknecht, 1974; Suzuka and Schuknecht, 1988) and in transgenic mice (Xiang et al., 2003), highlights the importance of supporting cells in promoting long-term survival of cochlear afferent neurons in the absence of hair cells.

Our findings suggest that cochlear supporting cells may play roles similar to those of glial cells, which are known to promote neuronal survival (Cui et al., 2001). Morphologically, cochlear supporting cells closely ensheath the unmyelinated peripheral terminals of afferent and efferent neurons within the organ of Corti, underneath IHCs and OHCs. Immunohistochemically, cochlear supporting cells share other similarities with glia, including expression of several glial markers (Anniko et al., 1986; Furness and Lehre, 1997; Vega et al., 1999; Rio et al., 2002). Therefore, supporting cells may play other glial-like roles, such as regulation of synaptic function (Ullian et al., 2001; Reddy et al., 2003).

The NRGs constitute a family of ligands for some members of the erbB family of receptor tyrosine kinases (for review, see Falls, 2003). Presently, there are four known NRGs, but except for NRG1, very little is known about their biological roles. NRG1 can directly bind to erbB3 and erbB4, but after ligand binding these receptors can also form heterodimers with erbB2. Because erbB3 does not have significant kinase activity, this receptor requires dimerization with either erbB2 or erbB4 to form functional receptors. Thus, a cell expressing either erbB4 alone or any combination of the three receptors can respond to NRG1. The findings that (1) SGNs express NRG1 and (2) supporting cells of the organ of Corti express erbB2 and erbB3 receptors suggest that these molecules may mediate interactions between these cells. In contrast, because hair cells express only erbB2, they are unlikely to be affected by any NRG. The dominant-negative erbB4 blocks the function of all the NRG receptors; however, this blockade is not ligand-specific, i.e., it should affect activation of the erbB receptors in response to any NRG. Thus, the possibility that other members of the NRG family play roles in the function of supporting cells remains to be determined.

Morley (1998), using in situ hybridization, reported that
SGNs are the only cochlear cells that express NRG1. Hansen et al. (2001) found NRG1 immunoreactivity in the SGNs and in their peripheral axons, suggesting that NRG1 produced by the SGNs is transported to the organ of Corti, where it could be released. Our immunostaining with NRG1 is in agreement with these observations (Fig. 1). There has been one report of NRG1 immunoreactivity in other cochlear cells (Zhang et al., 2002); however, this could reflect NRG1 produced by neurons and bound to the extracellular matrix, as has been shown at the neuromuscular junction (Goodearl et al., 1995; Sandrock et al., 1995). Our analysis of erbB receptor expression shows that, in the postnatal cochlea, supporting cells express erbB2 and erbB3, making them NRG1 responsive, whereas hair cells express only erbB2, indicating that they are not responsive to NRG1. Importantly, by immunostaining and in situ hybridization, we failed to detect erbB4 expression in the cochlea. Specifically, because the DN-erbB4 probe that we used is almost identical to the murine erbB4, the absence of hybridization in the wild-type cochlear tissue also indicates that erbB4 is not expressed in the wild-type cochlea. These results differ somewhat from those of a study reporting that supporting cells in the adult cochlea express erbB2, erbB3, and erbB4, whereas hair cells express erbB2 and erbB3 (Hume et al., 2003). The differences may be attributable to the different ages analyzed: P15 in the present study versus $4-12$ weeks in the Hume et al. (2003) study. Nevertheless, the specific expression of DN-erbB4 in supporting cells in our transgenic line shows that erbB receptors expressed by supporting cells are critical for the function of the adult cochlea.

In a previous study of the sciatic nerve of the same transgenic lines described here, we reported that expression of DN-erbB4 in nonmyelinating Schwann cells in this transgenic results in a small-fiber peripheral neuropathy involving loss of dorsal root ganglion (DRG) sensory neurons (Chen et al., 2003). Although the sciatic and cochlear phenotypes are similar in that both involve first the loss of sensory axons and then the loss of neuronal cell bodies, there are important differences between the effects of loss of erbB signaling in these cells and structures. First, when nonmyelinating Schwann cells stop responding to NRG, they undergo a cycle of cell proliferation and death, resulting in loss of the Remak bundle organization. In contrast, after losing erbB receptor function, cochlear supporting cells remain essentially intact, and the organization of the organ of Corti is maintained. This shows that erbB signaling does not control the survival or proliferation of adult supporting cells but rather their function. Second, the neuronal loss in the DRG occurs late and is gradual. 
In contrast, SGN loss in the cochlea is fast and catastrophic, indicating that the molecular changes in the supporting cells compromise neuronal survival in a direct manner and that supporting cells play an essential role in SGN survival in the adult. A third difference between the sciatic nerve and the cochlea is in the alterations in GDNF expression. In the sciatic nerve of transgenic mice, we found a significant reduction in GDNF, a factor produced by Schwann cells that normally increases after injury (Hammarberg et al., 1996). These results suggested that, within the sciatic nerve, erbB signaling in the nonmyelinating Schwann cells contributes to the regulation of GDNF expression in the normal and injured nerve and that the loss of DRG neurons may be, in part, a result of the reduction in GDNF expression in the nerve. In contrast, in the cochlea, GDNF expression was increased, as has been shown after acoustic trauma (Nam et al., 2000). This increase probably does not reflect changes in the supporting cells but rather in the myelinating Schwann cells. As in the sciatic nerve, loss of contact with the afferent fibers may induce GDNF expression in the Schwann cells as a protective mechanism. It is important to note that exogenously applied GDNF has been shown to promote the survival of SGNs in injury models (Altschuler et al., 1999; Yagi et al., 2000). Thus, it is unlikely that the increased GDNF expression contributes to the degeneration of SGNs in this mouse model. Moreover, our results suggest that the amount of GDNF produced endogenously in response to injury is not sufficient to promote neuronal survival, because most SGNs die in this transgenic model.

NT3, which is significantly reduced in the transgenic cochlea before the death of SGNs (Fig. 8), is likely a key factor in the neuronal degeneration seen in this study. The observation that NT3 is expressed in the adult inner ear (Stankovic and Corfas, 2003) by IHCs and supporting cells (Fig. 9) and the correlation between the reduction in NT3 expression and SGN death shown here suggest that this molecule plays roles in the inner ear beyond its critical roles in development. Our data indicate that, in the adult, type I but not type II SGNs require NT3 for their survival (Fig. 5). Studies of NT3 knock-out mice revealed that the lack of NT3 during embryonic development causes losses of both type I and type II SGNs, with more severe reduction of OHC than IHC innervation, and an almost complete loss of innervation in the basal turn (Fritzsch et al., 1997). This topographical neuronal loss during development is now believed to be caused by differential expression changes of neurotrophins NT3 and BDNF through development (Farinas et al., 2001), with both neurotrophins being functionally equivalent for developing SGNs, as demonstrated by replacement of either neurotrophin by the other (Coppola et al., 2001; Agerman et al., 2003; Tessarollo et al., 2004). Thus, the specificity in the loss of type I SGNs in the DN-erbB4expressing mice may be attributable to changes in the specific neurotrophins that adult SGN neurons require for survival or that erbB signaling only regulates neurotrophin expression in IHC supporting cells, and therefore only type I SGNs are affected by the DN-erbB4 expression.

Both hair cells and supporting cells have been shown to express NT3 mRNA in development (Pirvola et al., 1992; Fritzsch et al., 1999; Qun et al., 1999), and we found a similar pattern of expression in the adult, where no LacZ expression was found in other cells, including Schwann cells. Thus, the reduction in NT3 expression in the transgenic mice cannot be explained by a loss of neurons or Schwann cells but rather by changes in supporting cells and/or hair cells. We attempted to determine whether loss of erbB signaling results in significant reductions in NT3 expression in the supporting cells by generating homozygous transgenic

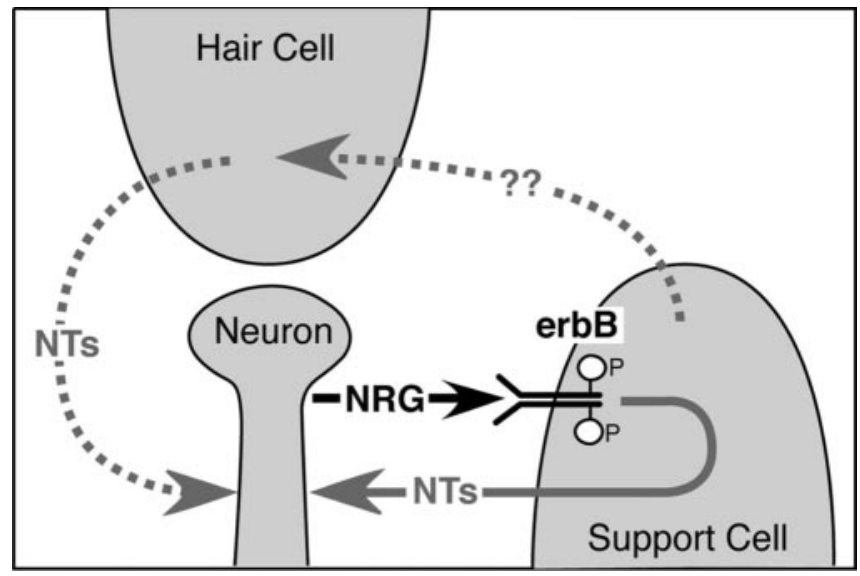

Figure 10. Schematic of putative NRG-erbB signaling in the cochlea. NRG expressed by SGNs activates erbB receptors in the supporting cells. erbB receptor signaling induces expression of neurotrophins (most likely NT3) by the supporting cells, which then induces the survival of the SGNs through their Trk receptors. An indirect pathway may also exist: e.g., supporting cells produce a factor that acts on hair cells, which then release neurotrophins.

mice that also have the NT3-LacZ knock-in (data not shown). Although there were some specimens from homozygous mice in which we saw a strong reduction in LacZ staining in supporting cells, these observations were not reproduced reliably, possibly because of saturation effects and other nonlinearities in staining intensity of LacZ reactions. Nevertheless, these experiments showed that the pattern of NT3 expression in homozygous mice did not change dramatically, i.e., LacZ staining was seen only in IHC and their supporting cells in both genotypes. Thus, we cannot determine conclusively whether the alterations in NT3 expression are specific to supporting cells or, alternatively, whether the DN-erbB4 expression in supporting cells may lead to a reduced NT3 expression in hair cells, which could contribute to the phenotype. In addition to NT3, we cannot discount the possibility that other factors also contribute to the neuronal loss. Nevertheless, the present results suggest a model for putative NRGerbB signaling in the cochlea (Fig. 10). In this model, NRG1 produced by SGNs would activate erbB receptors in the supporting cells, which then would induce the expression and release of NT3 by these cells, which would then promote the survival of the type I sensory neurons.

Other studies have also found evidence that NRG1 and NT3 mediate reciprocal interactions between neurons and glia. In the developing sympathetic nervous system, NRG1 produced by neuroblasts was shown to promote NT3 production by neighboring non-neuronal cells, which in turn promotes neuroblast survival and further differentiation (Verdi et al., 1996). Hansen et al. (2001) showed that NRG1 negatively regulates NT3 expression in spiral ganglion Schwann cells in culture at the same time that it induces their proliferation, suggesting that NRG1 and NT3 mediate reciprocal interactions between SGNs and Schwann cells. These observations, in conjunction with our results, suggest that SGNs may use NRG1 to regulate NT3 expression differently in different cell populations in the cochlea. On one hand, NRG1 may induce NT3 expression in supporting cells, and on the other hand, it may inhibit NT3 expression in Schwann cells. This may explain the very restricted pattern of NT3 expression in the adult cochlea and the lack of NT3 expression by Schwann cells (Fig. 9).

Other investigators have shown that supporting cells of the vestibular sensory epithelium express erbB receptors and that NRG induces these cells to proliferate (Zheng et al., 1999) and 
differentiate into hair cells (Montcouquiol and Corwin, 2001). Thus, NRG-erbB signaling in the vestibular epithelium may play a role in the generation of hair cells. These findings raise the possibility that NRG-erbB signaling could play a similar role in the development of the cochlea, but this has not been demonstrated. Our results show that in the adult cochlea, erbB signaling in the supporting cells does not regulate their survival or proliferation. Thus, the downstream effects of erbB signaling in supporting cells may differ between inner ear regions (cochlea vs vestibular organs) or between developing and adult organs. The latter possibility has been observed for erbB signaling in Schwann cells. During development, erbB signaling induces proliferation of Schwann cell precursors (Dong et al., 1995), whereas in the adult it prevents the proliferation of nonmyelinating Schwann cells (Chen et al., 2003).

In the past decade, the presence of primary neuronal degeneration as a significant cause of human deafness has become appreciated because of the more widespread application of otoacoustic emission testing. Such testing has documented the presence of functioning hair cells in cochleas of deaf individuals with absent auditory evoked potentials (Starr et al., 1996). This general phenomenon has been termed "auditory neuropathy" and is thought to be present in at least $10 \%$ of children with language and hearing problems (Berlin et al., 2003). Although several mechanisms may contribute to the pathogenesis of auditory neuropathy (Parkinson et al., 2001; Varga et al., 2003), our study suggests that disturbances in NRG-erbB signaling, NT3trkC signaling, or the function of supporting cells in the adult cochlea may be one cause of this class of hearing impairment.

\section{References}

Adlkofer K, Lai C (2000) Role of neuregulins in glial cell development. Glia 29:104-111.

Agerman K, Hjerling-Leffler J, Blanchard MP, Scarfone E, Canlon B, Nosrat C, Ernfors P (2003) BDNF gene replacement reveals multiple mechanisms for establishing neurotrophin specificity during sensory nervous system development. Development 130:1479-1491.

Altschuler RA, Cho Y, Ylikoski J, Pirvola U, Magal E, Miller JM (1999) Rescue and regrowth of sensory nerves following deafferentation by neurotrophic factors. Ann NY Acad Sci 884:305-311.

Anniko M, Thornell LE, Gustavsson H, Virtanen I (1986) Intermediate filaments in the newborn inner ear of the mouse. ORL J Otorhinolaryngol Relat Spec 48:98-106.

Berglund AM, Ryugo DK (1991) Neurofilament antibodies and spiral ganglion neurons of the mammalian cochlea. J Comp Neurol 306:393-408.

Berlin CI, Hood L, Morlet T, Rose K, Brashears S (2003) Auditory neuropathy/dys-synchrony: diagnosis and management. Ment Retard Dev Disabil Res Rev 9:225-231.

Brenner M, Kisseberth WC, Su Y, Besnard F, Messing A (1994) GFAP promoter directs astrocyte-specific expression in transgenic mice. J Neurosci 14:1030-1037.

Chen S, Rio C, Ji RR, Dikkes P, Coggeshall RE, Woolf CJ, Corfas G (2003) Disruption of ErbB receptor signaling in adult non-myelinating Schwann cells causes progressive sensory loss. Nat Neurosci 6:1186-1193.

Cohen JA, Yachnis AT, Arai M, Davis JG, Scherer SS (1992) Expression of the neu proto-oncogene by Schwann cells during peripheral nerve development and Wallerian degeneration. J Neurosci Res 31:622-634.

Coppola V, Kucera J, Palko ME, Martinez-De Velasco J, Lyons WE, Fritzsch B, Tessarollo L (2001) Dissection of NT3 functions in vivo by gene replacement strategy. Development 128:4315-4327.

Corfas G, Rosen KM, Aratake H, Krauss R, Fischbach GD (1995) Differential expression of ARIA isoforms in the rat brain. Neuron 14:103-115.

Cui W, Allen ND, Skynner M, Gusterson B, Clark AJ (2001) Inducible ablation of astrocytes shows that these cells are required for neuronal survival in the adult brain. Glia 34:272-282.

Dong Z, Brennan A, Liu N, Yarden Y, Lefkowitz G, Mirsky R, Jessen KR (1995) Neu differentiation factor is a neuron-glia signal and regulates survival, proliferation, and maturation of rat Schwann cell precursors. Neuron 15:585-596.

Erickson SL, O'Shea KS, Ghaboosi N, Loverro L, Frantz G, Bauer M, Lu LH, Moore MW (1997) ErbB3 is required for normal cerebellar and cardiac development: a comparison with ErbB2- and heregulin-deficient mice. Development 124:4999-5011.

Falls DL (2003) Neuregulins: functions, forms, and signaling strategies. Exp Cell Res 284:14-30.

Farinas I, Jones KR, Backus C, Wang XY, Reichardt LF (1994) Severe sensory and sympathetic deficits in mice lacking neurotrophin-3. Nature 369:658-661.

Farinas I, Jones KR, Tessarollo L, Vigers AJ, Huang E, Kirstein M, de Caprona DC, Coppola V, Backus C, Reichardt LF, Fritzsch B (2001) Spatial shaping of cochlear innervation by temporally regulated neurotrophin expression. J Neurosci 21:6170-6180.

Fekete DM, Wu DK (2002) Revisiting cell fate specification in the inner ear. Curr Opin Neurobiol 12:35-42.

Fritzsch B, Farinas I, Reichardt LF (1997) Lack of neurotrophin 3 causes losses of both classes of spiral ganglion neurons in the cochlea in a regionspecific fashion. J Neurosci 17:6213-6225.

Fritzsch B, Pirvola U, Ylikoski J (1999) Making and breaking the innervation of the ear: neurotrophic support during ear development and its clinical implications. Cell Tissue Res 295:369-382.

Furness DN, Lehre KP (1997) Immunocytochemical localization of a highaffinity glutamate-aspartate transporter, GLAST, in the rat and guineapig cochlea. Eur J Neurosci 9:1961-1969.

Gassmann M, Casagranda F, Orioli D, Simon H, Lai C, Klein R, Lemke G (1995) Aberrant neural and cardiac development in mice lacking the ErbB4 neuregulin receptor. Nature 378:390-394.

Goodearl AD, Yee AG, Sandrock Jr AW, Corfas G, Fischbach GD (1995) ARIA is concentrated in the synaptic basal lamina of the developing chick neuromuscular junction. J Cell Biol 130:1423-1434.

Greenwood DD (1990) A cochlear frequency-posiiton function for several species-29 years later. J Acoust Soc Am 87:2592-2605.

Hammarberg H, Piehl F, Cullheim S, Fjell J, Hokfelt T, Fried K (1996) GDNF mRNA in Schwann cells and DRG satellite cells after chronic sciatic nerve injury. NeuroReport 7:857-860.

Hansen MR, Vijapurkar U, Koland JG, Green SH (2001) Reciprocal signaling between spiral ganglion neurons and Schwann cells involves neuregulin and neurotrophins. Hear Res 161:87-98.

Hume CR, Kirkegaard M, Oesterle EC (2003) ErbB expression: the mouse inner ear and maturation of the mitogenic response to heregulin. J Assoc Res Otolaryngol 4:422-443.

Jessen KR, Morgan L, Stewart HJ, Mirsky R (1990) Three markers of adult non-myelin-forming Schwann cells, 217c(Ran-1), A5E3 and GFAP: development and regulation by neuron-Schwann cell interactions. Development 109:91-103.

Johnsson LG (1974) Sequence of degeneration of Corti's organ and its firstorder neurons. Ann Otol Rhinol Laryngol 83:294-303.

Lee KF, Simon H, Chen H, Bates B, Hung MC, Hauser C (1995) Requirement for neuregulin receptor erbB2 in neural and cardiac development. Nature 378:394-398.

Liberman MC (1980) Morphological differences among radial afferent fibers in the cat cochlea: an electron-microscopic study of serial sections. Hear Res 3:45-63.

Liberman MC, Kiang NY (1978) Acoustic trauma in cats. Cochlear pathology and auditory-nerve activity. Acta Otolaryngol [Suppl] 358:1-63.

Meyer D, Birchmeier C (1995) Multiple essential functions of neuregulin in development. Nature 378:386-390.

Montcouquiol M, Corwin JT (2001) Intracellular signals that control cell proliferation in mammalian balance epithelia: key roles for phosphatidylinositol-3 kinase, mammalian target of rapamycin, and S6 kinases in preference to calcium, protein kinase $\mathrm{C}$, and mitogen-activated protein kinase. J Neurosci 21:570-580.

Morley BJ (1998) ARIA is heavily expressed in rat peripheral auditory and vestibular ganglia. Brain Res Mol Brain Res 54:170-174.

Mueller M, von Huenerbein K, Hoidis S, Smolders JWT (2004) A physiological place-frequency map of the cochlea in the mouse. Paper presented at 27th Midwinter Meeting of the Association for Research in Otolaryngology. Daytona Beach, FL, February.

Nam YJ, Stover T, Hartman SS, Altschuler RA (2000) Upregulation of glial 
cell line-derived neurotrophic factor (GDNF) in the rat cochlea following noise. Hear Res 146:1-6.

Pack AK, Slepecky NB (1995) Cytoskeletal and calcium-binding proteins in the mammalian organ of Corti: cell type-specific proteins displaying longitudinal and radial gradients. Hear Res 91:119-135.

Parkinson NJ, Olsson CL, Hallows JL, McKee-Johnson J, Keogh BP, NobenTrauth K, Kujawa SG, Tempel BL (2001) Mutant beta-spectrin 4 causes auditory and motor neuropathies in quivering mice. Nat Genet 29:61-65.

Pirvola U, Ylikoski J, Palgi J, Lehtonen E, Arumae U, Saarma M (1992) Brain-derived neurotrophic factor and neurotrophin 3 mRNAs in the peripheral target fields of developing inner ear ganglia. Proc Natl Acad Sci USA 89:9915-9919.

Prevot V, Rio C, Cho GJ, Lomniczi A, Heger S, Neville CM, Rosenthal NA, Ojeda SR, Corfas G (2003) Normal female sexual development requires neuregulin-erbB receptor signaling in hypothalamic astrocytes. J Neurosci 23:230-239.

Qun LX, Pirvola U, Saarma M, Ylikoski J (1999) Neurotrophic factors in the auditory periphery. Ann NY Acad Sci 884:292-304.

Reddy LV, Koirala S, Sugiura Y, Herrera AA, Ko CP (2003) Glial cells maintain synaptic structure and function and promote development of the neuromuscular junction in vivo. Neuron 40:563-580.

Riethmacher D, Sonnenberg-Riethmacher E, Brinkmann V, Yamaai T, Lewin GR, Birchmeier C (1997) Severe neuropathies in mice with targeted mutations in the ErbB3 receptor. Nature 389:725-730.

Rio C, Rieff HI, Qi P, Khurana TS, Corfas G (1997) Neuregulin and erbB receptors play a critical role in neuronal migration. Neuron 19:39-50.

Rio C, Dikkes P, Liberman MC, Corfas G (2002) Glial fibrillary acidic protein expression and promoter activity in the inner ear of developing and adult mice. J Comp Neurol 442:156-162.

Sandrock Jr AW, Goodearl AD, Yin QW, Chang D, Fischbach GD (1995) ARIA is concentrated in nerve terminals at neuromuscular junctions and at other synapses. J Neurosci 15:6124-6136.

Schuknecht HF (1974) Pathology of the ear. Cambridge, MA: Harvard UP.

Stankovic KM, Corfas G (2003) Real-time quantitative RT-PCR for lowabundance transcripts in the inner ear: analysis of neurotrophic factor expression. Hear Res 185:97-108.
Starr A, Picton TW, Sininger Y, Hood LJ, Berlin CI (1996) Auditory neuropathy. Brain 119:741-753.

Suzuka Y, Schuknecht HF (1988) Retrograde cochlear neuronal degeneration in human subjects. Acta Otolaryngol [Suppl] 450:1-20.

Taberner AM, Liberman MC (2003) Response properties of single auditory nerve fibers in CBA/CaJ mice. Paper presented at 26th Midwinter Meeting of the Association for Research in Otolaryngology, Daytona Beach, FL, February.

Tessarollo L, Coppola V, Fritzsch B (2004) NT-3 replacement with brainderived neurotrophic factor redirects vestibular nerve fibers to the cochlea. J Neurosci 24:2575-2584.

Ullian EM, Sapperstein SK, Christopherson KS, Barres BA (2001) Control of synapse number by glia. Science 291:657-661.

Varga R, Kelley PM, Keats BJ, Starr A, Leal SM, Cohn E, Kimberling WJ (2003) Non-syndromic recessive auditory neuropathy is the result of mutations in the otoferlin (OTOF) gene. J Med Genet 40:45-50.

Vega JA, San Jose I, Cabo R, Rodriguez S, Represa J (1999) Trks and p75 genes are differentially expressed in the inner ear of human embryos. What may Trks and p75 null mutant mice suggest on human development? Neurosci Lett 272:103-106.

Verdi JM, Groves AK, Farinas I, Jones K, Marchionni MA, Reichardt LF, Anderson DJ (1996) A reciprocal cell-cell interaction mediated by NT-3 and neuregulins controls the early survival and development of sympathetic neuroblasts. Neuron 16:515-527.

Xiang M, Maklad A, Pirvola U, Fritzsch B (2003) Brn3c null mutant mice show long-term, incomplete retention of some afferent inner ear innervation. BMC Neurosci 4:2.

Yagi M, Kanzaki S, Kawamoto K, Shin B, Shah PP, Magal E, Sheng J, Raphael Y (2000) Spiral ganglion neurons are protected from degeneration by GDNF gene therapy. J Assoc Res Otolaryngol 1:315-325.

Zhang M, Ding D, Salvi R (2002) Expression of heregulin and ErbB/Her receptors in adult chinchilla cochlear and vestibular sensory epithelium. Hear Res 169:56-68.

Zheng JL, Frantz G, Lewis AK, Sliwkowski M, Gao WQ (1999) Heregulin enhances regenerative proliferation in postnatal rat utricular sensory epithelium after ototoxic damage. J Neurocytol 28:901-912. 